\title{
BIBLIOGRÁFIA
}

\section{A magyar nyomda-, könyv-, sajtó- és könyvtártörténeti szakirodalom 2014-ben}

Röviditések:

$\begin{array}{ll}\text { GeodKart } & =\text { Geodézia és Kartográfia } \\ \mathrm{HK} & =\text { Hadtörténelmi Közlemények } \\ \mathrm{It} & =\text { Irodalomtörténet } \\ \text { ItK } & =\text { Irodalomtörténeti Közlemények } \\ \text { KF } & =\text { Könyvtári Figyelö } \\ \text { KKK } & =\text { Könyv, Könyvtár, Könyvtáros } \\ \text { KN } & =\text { Könyv és Nevelés } \\ \text { MG } & =\text { Magyar Grafika } \\ \text { MKsz } & =\text { Magyar Könyvszemle } \\ \text { MTud } & =\text { Magyar Tudomány } \\ \text { MVízjel } & =\text { Magyar Vízjel } \\ \text { MüvtörtÉrt. } & =\text { Múvészettörténeti Értesítő }\end{array}$

Certamen I... $\quad=$ Certamen I. Előadások a Magyar Tudomány Napján az Erdélyi Múzeum-Egyesület I. Szakosztályában. Nyelv-, irodalom-, néprajztudomány, régészet, történelem, müvészettörténet / szerk. EgYEd Emese, PAKó László, WeIsz Attila. Kolozsvár: Erdélyi Múzeum-Egyes., 2013. 556 p.

Egyházi, családi és = Egyházi, családi és asszonykönyvtárak. Könyvtártörténeti szakdolasszonykönyvtárak... gozatok / szerk. Muzs Krisztina. Szeged: Primaware, 2014. 523 p. (Művelődéstörténeti könyvtár. Könyv- és könyvtártörténelem)

Források = Források és hagyományképek/szerk. STEMLER Ágnes. Bp.: Bibl. Natioés hagyományképek... nalis Hungariae-Gondolat, 2014. 199 p. (Bibliotheca scientiae \& artis)

A határon túli magyar sajtó...

= A határon túli magyar sajtó Trianontól a XX. század végéig. Fejezetek a magyar sajtószabadság történetéböl / szerk. Apró István, PAÁL Vince. Bp.: Médiatud. Int., 2014. 321 p. (Médiatudományi könyvtár)

A huszadik század mezsgyéjén...

= A huszadik század mezsgyéjén. Haiman György (1914-1996) születésének 100. évfordulója emlékére / összeáll. FüZESNÉ HudÁK Julianna, Haiman Ágnes; szerk. HradeczKy Moni. Gyomaendrőd: Kner Múz. és Kv. Alapítvány, 2014. 246 p.

Képes világ...

$=$ „Képes világ”. Tudományos konferencia a 19. századi magyarországi illusztrált sajtóról. A Budapesti Történeti Múzeum és az Országos Széchényi Könyvtár közös rendezvénye / szerk. SzvoBoda DomÁnszky Gabriella. Bp.: BTM-OSZK, 2014. 399 p. (Tanulmányok Budapest múltjából; 39.) 
Pedagógia, = Pedagógia, oktatás, könyvtár. Ünnepi tanulmányok F. Dárdai Ágnes oktatás, könyvtár... tiszteletére / szerk. CsókA-JAKSA Helga, Schmelczer-PoHÁnKa Éva, SzeberÉnyi Gábor. Pécs: PTE Egyetemi Kvt. és Tudásközp., 2014. $587 \mathrm{p}$.

A sajtó kultúraközvetítő... = A sajtó kultúraközvetítő szerepe, 1867-1945. Tanulmányok / szerk. PAÁL Vince. Bp.: MTA BTK, 2014. 111 p. (Médiatudományi könyvek)

Szinnyei és követöi... = Szinnyei és követöi. Id. Szinnyei József halálának 100. évfordulójáról megemlékező centenáriumi emlékkönyv / szerk. SzÖNYI Éva. Bp.: OSZK-Gondolat-MKE, 2014. 185 p. (Nemzeti téka)

Textológia... = Textológia, filológia, értelmezés. Klasszikus magyar irodalom / szerk. Czifra Mariann, Szilágyi Márton. Debrecen: Debreceni Egy. K., 2014. 410 p.

A zsoltártól = A zsoltártól a rózsaszín regényig. Fejezetek a magyar női művelődés a rózsaszín regényig... történetéből. Tanulmánykötet és adattár a Petőfi Irodalmi Múzeum és az MTA Bölcsészettudományi Kutatóközpont Művészettörténeti Intézete együttmüködésében a Petőfi Irodalmi Múzeumban rendezett kiállításhoz / szerk. PAPP Júlia. Bp.: PIM, 2014. 293 p.

\section{Általános és összefoglaló munkák, elvi kérdések}

FiLeP Tamás Gusztáv: „Mindegy, hogy a szikla kaukázusi-e, erdélyi vagy tibeti”. Bánffy Miklós és a kultúrpolitika, 1925-1939 = Bánffy Miklós-emlékkonferencia. 2013. december 18. / szerk. PAPP Endre. Bp.: MMA, 2014. 189-208.

FÖLDVÁRY Miklós István: A Liturgiatörténeti Kutatócsoport digitális forrásgyüjteménye $=$ MEgyházzene (21.) 2013/2014. 1. 101-111.

GoluB Xénia: Szláv kéziratok és régi nyomtatványok katalógusrevíziója a nyíregyházi Szent Atanáz Görögkatolikus Hittudományi Főiskola könyvtárában $=$ Athanasiana (38.) 2014. 143-154.

LIPTÁK Dorottya: Írjunk médiatörténeteket, de hogyan? Historiográfiai megközelítés $=\mathrm{MKsz}$ (130.) 2014. 4. 431-451.

Magyar müvelödéstörténeti lexikon. Középkor és kora újkor / föszerk. KöszegHY Péter; szerk. TAMÁs Zsuzsanna. Bp.: Balassi, 2003-2014.

14., Mutatók. 2014. 360 p.

Metelko, Marina: Books at the crossroads. The book culture of Zagreb in the late medieval period $=$ Annual of medieval studies at the CEU (20.) 2014. 165-179. ill.
MonoK István: Un nouveau regard sur le patrimoine culturel. Les contacts entre réseaux humanistes et l'analyse du corpus des livres $\mathrm{du}$ XVIe siècle $=$ Histoire et civilisation $\mathrm{du}$ livre (9.) 2014. 129-137.

MonoK István: A párizsi könyv elterjedése Közép-Európában. 15-18. század = Pedagógia, oktatás, könyvtár... 361-381.

MonoK István: Seebergi Sasváry Zoltán könyvtörténeti magánkiadványai $=$ MKsz (130.) 2014. 1. 110-112.

RÁKAI Orsolya: Médiatörténet a kultúratudományok után-között = MKsz (130.) 2014. 4. 415-430.

SzABÓ András: Női művelődés a 16. századi Magyarországon $=$ A zsoltártól a rózsaszín regényig... 71-77. ill.

SzŐTs Zoltán Oszkár: Az Országos Széchényi Könyvtár egykori első világháborús gyüjteménye. Bp.: OSZK-Gondolat, 2014. 355 p. ill. (Nemzeti téka)

Teszelszky, Kees: Szenci Molnár Albert elveszettnek hitt Igaz Vallás portréja (1606) avagy Holland-flamand-magyar szellemi kapcsolatok a kora újkorban $=$ True Religion: a lost portrait by Albert Szenci Molnár (1606) or Dutch-Flemish-Hungarian intellectual relations in the early-modern period. Bp.: ELTE BTK Középkori és Kora Újkori 
M. Történeti Tansz.-Transylvania Emlékeiért Tud. Egyes., 2014. 181 p. ill.

UGRY Bálint: Miként világította meg „Utrecht csillagának" fénye kora újkori hazai müvelődésünket? Adalékok Anna Maria van Schurman magyaroroszági recepciójának történetéhez $=$ A zsoltártól a rózsaszín regényig... 127-139. ill.

VeróK Attila: Egy magyarországi értelmiségi európai tudományos karrierje a 18. században. Martin Schmeizel és a polihisztorizmus $=$ Értelmiségi karriertörténetek, kapcsolathálók, írócsoportosulások / szerk. BIRÓ Annamária, BoKA László. Nagyvárad: Partium; Bp.: Reciti, 2014. 55-70.

VeróK Attila: Auf dem Weg zur Konzipierung der ungarländischen Nationalbibliografie im 18. Jahrhundert? Martin Schmeizels Tätigkeit als Bibliograf $=$ Az Eszterházy Károly Föiskola tudományos közleményei. Germanistische Studien (9.) 2013. 59-69.

A zsoltártól a rózsaszín regényig. Fejezetek a magyar női művelődés történetéből. Tanulmánykötet és adattár a Petőfi Irodalmi Múzeum és az MTA Bölcsészettudományi Kutatóközpont Mủvészettörténeti Intézete együttmüködésében a Petőfi Irodalmi Múzeumban rendezett kiállításhoz / szerk. PAPP Júlia. Bp.: PIM, 2014. 293 p. ill.

A Budapesten, 2014. ápr. 3-nov. 25. között rendezett kiállítás alkalmából

\section{Bibliográfiák, repertóriumok, katalógusok}

Bibliográfia + Válogatás női művelődési témájú kéziratokból és nyomtatványokból = A zsoltártól a rózsaszín regényig... 203228., 231-261.

EMőDI András: A nagyváradi egyházmegye alsópapságának könyvkultúrája a korai újkor végén. 18. századi plébániai könyvjegyzékek, személyi gyüjtemények fennmaradt kötetei. Bp.: Nk. Magyarságtud. Társ.; Szeged: SZTE; Nagyvárad: Partiumi Keresztény Egy., 2014. LVIII, 286 p. ill. (Adattár XVI-XVIII. századi szellemi mozgalmaink történetéhez; 19/4.)
Ferenczi Ilona: A gregoriánkutatás mostohagyermeke: az anyanyelvü gregorián. A magyar nyelvű graduálok katalógusa $=$ Zenetudományi dolgozatok, 1978-2012. 35 éves jubileumi kötet / szerk. Kiss Gábor. Bp.: MTA BTK ZTI, 2014. 77-81.

FÜZESNÉ HUdÁK Julianna: Irodalomjegyzék. Haiman György publikációi + Válogatott publikációk, interjúk Haiman Györgyről = A huszadik század mezsgyéjén... 223-242., 243247.

A magyar sajtótörténet válogatott bibliográfiája, 1705-1944 / összeáll. LaKatos Éva. Bp., OSZK, 2010-

5. köt. Pótlások, kiegészítések. 2014. 177. p.

\section{Cenzúratörténet és más jogi szabályozások}

DöBÖR András: Sajtó és cenzúra a 18. és a 19. század fordulóján Magyarországon = Médiakutató (15.) 2014. 2. 17-28.

PruzsinszKy Sándor: Halhatatlan cenzúra. Bp.: Médiatud. Int., 2014. 240 p. (Médiatudományi könyvtár; 12.)

UnGVÁRY Krisztián: „Lesték Ilia Mihály minden szavát”. Egy magyar értelmiségi és az állambiztonság = Parnasszus (20.) 2014.3. 63-71. A Tiszatáj betiltásáról

\section{Könyvtörténet \\ Kéziratosság, kódexek}

BuzÁsı Enikő: A magyar korona eddig ismert legkorábbi autentikus ábrázolásának keletkezéséről. A Szent Korona a Habsburg Ehrenspiegelben = MüvtörtÉrt (63.) 2014. 2. 217 264. ill.

Corvina Augusta. Die Handschriften des Königs Matthias Corvinus in der Herzog August Bibliothek Wolfenbüttel / hrsg. Edina ZsupÁn, Mitarb. Christian Heitzmann. Bp.: Bibl. Nat. Hung., 2014. 319 p. ill. (Supplementum Corvinianum; 3.). (Ex Bibliotheca Corviniana)

A tanulmányok váltakozva német és angol nyelven. 
CsÁkó Judit: A Magyar-lengyel Krónika és a hazai elbeszélő hagyomány = Századok (148.) 2014. 2. 287-334. ill.

Függelékben a Magyar-lengyel Krónika szöveghagyománya (Karácsonyi Béla sztemmája alapján)

Csorba Dávid: Adalékok Debreceni Ember Pál kéziratban maradt szövegeinek irodalmi hagyatékához = Egyháztört. Szle (15.) 2014. 4. 51-76., 111.

Mellékletek: 1. sz.: A Canones ecclesiastici, in quinque classes distributi...c. mü elözéklapjain található kézírásos bejegyzések; 2. sz.: a protocullum eredeti szövegének betühív és Ember Pál kéziratos lejegyzésének közlése; 3-4. sz.: latin esküformulák változatainak közlése

Csukovits Enikő: Magyarország helye KeletEurópában. A Descriptio Europae Orientalis országleírásai $=$ Archivariorum historicorumque magistra. Történeti tanulmányok Bak Borbála tanárnő 70. születésnapjára / szerk. KÁDÁr Zsófia, LAKATos Bálint, ZARNócZKi Áron. Bp.: M. Levéltárosok Egyes., 2013. 71-82.

CZagány Zsuzsa: Töredék, kódex, rítus, hagyomány. 2. A Váradi Szekvencionále újonnan előkerült darabja = Zenetudományi dolgozatok, 1978-2012. 35 éves jubileumi kötet / szerk. KIss Gábor. Bp.: MTA BTK ZTI, 2014. 45-56. ill.

Doncsecz Etelka: „Ez az írás éppen nem kedvez a'németnek”. Szaicz Leó Magyar Világ címü történeti munkájáról $=$ Textológia... 351-372.

FARKAS Gábor Farkas: A Budai Krónika eddig ismeretlen 18. századi kézirata $=\mathrm{MKsz}$ (130.) 2014. 2. 277-280.

FARKAS Gábor Farkas: Egy kalocsai ősnyomtatvány és az Államvédelmi Hatóság = MKsz (130.) 2014. 3. 370-373.

FöLDESI Ferenc: Az esztergomi Porta speciosa egy feliratáról = Tér(v)iszonyok és térkép(zet)ek / szerk. Bíró Csilla, Visy Beatrix. Bp.: Bibl. Nationalis Hungariae-Gondolat, 2014. 130136. (Bibliotheca scientiae \& artis)

GILÁNYI Gabriella: Középkori kottás töredékek újrafelfedezése a Központi Papnevelő Inté- zet Pálos Könyvtárában = Zenetudományi dolgozatok, 1978-2012. 35 éves jubileumi kötet / szerk. Kiss Gábor. Bp.: MTA BTK ZTI, 2014. 389-393.

JuHÁsz Erika: A Húsvéti krónika. Prolegomena. Bp.: Argumentum, 2014. 152 p. (Apollo könyvtár; 35.)

KISDI Klára: Egy figyelemreméltó Ars notoriatöredék a Capreolus-kötet egykori kötéséből = MKsz (130.) 2014. 3. 367-369.

Az Ars notoria töredék leírásával

KNAPP Éva: A történeti könyvállományok bővülési lehetősége - 1800 előtti ismeretlen nyomtatványok azonosítása $=$ KF (24.) 2014. 2. $167-172$.

KovÁcs Andrea: A középkori magyarországi Szent Anna-kultusz = Zenetudományi dolgozatok, 1978-2012. 35 éves jubileumi kötet / szerk. Kiss Gábor. Bp.: MTA BTK ZTI, 2014. 33-44.

LAuf Judit: Az Érsekújvári kódex és a Makula nélkül való tükör. A középkori magyar passióhagyomány nyomai a 18. századi kegyességi irodalomban = MKsz (130.) 2014 . 2. 218-236. ill.

Táblázat a Makula nélkül való tükör forrásairól

LÁzs Sándor: A Döbrentei-kódex rejtvényének megoldása = ItK (118.) 2014. 6. 784-801.

MaczelKa Csaba: Angol szerzők idézettsége peregrinációs albumainkban $=$ Értelmiségi karriertörténetek, kapcsolathálók, írócsoportosulások / szerk. BiRó Annamária, BOKA László. Nagyvárad: Partium; Bp.: Reciti, 2014. 41-54.

MedGyesy-SchmikLi Norbert: Jezsuita iskoladráma-színlapok, drámaszövegek és periocha-töredékek a Pannonhalmi Főapátsági Könyvtár Kézirattárában. Vizsgált forráscsoportunk: iskoladráma-színlapok $=$ Collectanea Sancti Martini (2.) 2014. 101-116.

Mroziewicz, Karolina: The history of medieval Hungary in the illustrated seventeenth-century lives of Saints = Annual of medieval studies at the CEU (20.) 2014. 180-199. ill.

NAGY Emőke: Szent Anna kultuszának jegyei a Teleki-, Kazinczy- és Érdy-kódex alapján $=$ Certamen I.... 35-48. 
NÉMETH S. Katalin: Német utazó - magyar bibliá$\mathrm{val}=\mathrm{ItK}$ (118.) 2014. 5. 661-669. ill.

OfFner, Robert: A XVI. századi erdélyi szász orvosok nyelve és Paulus Kyr egészségtankönyve, Brassó 1551 = MOrvosi Nyelv (14.) 2014. 2. 99-106. ill.

PoHÁNKA Éva: A Klimo Könyvtár „kincsei”. 1. Johannes Menestarffer, Chronica Hungarorum, Bécs, 1481, kézirat $=$ MKsz (130.) 2014. 2. 237-252.

RoKAY Zoltán: Egy Corvina a jezsuita tradícióban = Magyar Sion (8.) 2014. 1. 49-55. ill. Az Österreichische Nationalbibliothek-ban őrzött Cod. 1037 jelzetü, [Pseudo-]Cyrillus: Speculum sapientiae címü kódexről

SZENTGYÖRGYI Rudolf: A tihanyi apátság alapítólevele 1. Az alapítólevél szövege, diplomatikai és nyelvi leírása. Közread. ELTE BTK. Bp.: ELTE Eötvös K., 2014. 120 p. ill.

SzoLIva Gábriel: Utólagos zenei bejegyzések a Budai pszaltérium-ban = MEgyházzene (21.) 2013/2014. 1. 11-20. ill.

Az esztergomi Főszékesegyházi Könyvtárban örzött Ms I.3c jelzetü dokumentumról

TömPE Péter: Alkímia és középkori orvoslás. A Kalocsai Érseki Könyvtár ritkasága = Természet Világa (145.) 2014. 10. 434437. ill.

VADAI István: Balassi Bálint elvegyült énekei = ItK (118.) 2014. 3. 393-402.

VISKolcz Noémi: Ulisse Aldrovandi müveinek összkiadása a 17. századból az SZTE Klebelsberg Könyvtárban = MKsz (130.) 2014. 2 . 163-179. ill.

VladÁr Zsuzsa, C.: A Halotti beszéd kétféle latin fordítása. Sajnovics Demonstratiójában és Révai Antiquitatesában $=$ Források és hagyományképek... 179-188. ill.

WeHLI Tünde: Gertrúd királyné imakönyvvel a kezében $=$ A zsoltártól a rózsaszín regényig... 61-62. ill.

Zsoldos Endre: Egy csillagászati kézirat a kiskartali Podmaniczky-Degenfeld-könyvtárból = MKsz (130.) 2014. 1. 85-89.

Az MTA Csillagászati és Földtudományi Kutatóközpont Konkoly Thege Miklós Csillagászati Intézet könyvtárában örzött dokumentumról
Zsupán Edina: Locus bibliothecae. A könyvtár mint valós tér szerepe a kora újkori bibliotheca-laudatióban $=$ Tér(v)iszonyok és térkép(zet)ek / szerk. Bíró Csilla, VISY Beatrix. Bp.: Bibl. Nationalis Hungariae-Gondolat, 2014. 137-145.

\section{Nyomda-, nyomdászattörténet}

\section{Több évszázadot érintő munkák}

BÁnfi Szilvia-Ecsedy Judit, V.: A magyarországi nyomdászat képes krónikája, 14731700. Bp.: OSZK-Balassi, 2014. 219 p. ill.

ECSEDY Judit, V.: Ismerjük-e régi nyomdászainkat? = KF (24.) 2014. 2. 199-206.

SimOn Melinda: Kiadói és nyomdászjelvények. Hagyomány és korszerüség. Bp.: Balassi, 2014. 223 p. ill.

Timkó György: A Kossuth Nyomda képes krónikája, 1884-2006. Bp.: saját kiadás, 2014. 106 p. ill.

15. század

Pogányné Rózsa Gabriella: Táblanyomatok és dúckönyvek - a nyomtatványok elötti „nyomtatványok” = KKK (23.) 2014. 11/12. 52-60.

17. század

Ecsedy Judit, V.: A régi magyarországi nyomdák betüi és díszei, XVII. század. Bp.: Balassi-OSZK, 2010-

2/1. Kelet-magyarországi és erdélyi nyomdák. Lőcse, Kassa. Tanulmányok és katalógus / BÁNFI Szilvia et al. 2014. 376 p. (Hungaria typographica; 2.)

$2 / 2$. Kelet-magyarországi és erdélyi nyomdák. Löcse, Kassa. Illusztrációk / BÁNFI Szilvia et al. 2014. p. 385-1215. (Hungaria typographica; 2.)

TrajtLer Dóra Ágnes: A centenárium. A reformáció százéves évfordulója a régi magyarországi nyomtatványok tükrében $=$ Credo (20.) 2014. 4. Tanúk és tanulságok. 20-28. 
18. század

BÁNFI Szilvia: A budai Landerer-tipográfia nyomdakészletének tükrében $=$ Források és hagyományképek... 140-156. ill.

Ecsedy Judit, V.: Kolozsvári nyomdászok Utrechtben és Bécsben $=$ MG (58.) 2014. 2 . 74-77. ill.

Hudi József: A pápai Főiskolai Nyomda üzletpolitikája a reformkorban $=$ Piacok a társadalomban és a történelemben. A Hajnal István Kör - Társadalomtörténeti Egyesület 2012. évi, debreceni konferenciájának kötete / szerk. Halmos Károly, Kiss Zsuzsanna, KLEMENT Judit. Bp.: Hajnal I. Kör Társadalomtört. Egyes., 2014. 191-198., 532-533.

19. század

Kocsis Lajos: A csíkszeredai világi nyomdászat kezdetei, 1882-1885 = MKsz (130.) 2014. 1. 90-93.

PÁlfi József: A váradi nyomdászat kátékiadványai = Ref. Szle (107.) 2014. 2. 131-146.

PÁLYI Zsófia Kata: A Magyar Királyi Telekzeti Kőnyomda Budán = Catastrum (1.) 2014. 1 . 2-19. ill.

A Magyar Királyi Telekzeti/Kataszteri Könyomdában készült térképek jegyzékével

\section{9-20. század}

KIss Erika: Nyomdák és nyomdászok Jászberényben, 1856-2009 = Jászkunság 2014. 2. 121-137. ill.

Simon Melinda: A jelvényrajzoló Butkovszky Bertalan = MKsz (130.) 2014. 3. 353-366. ill. Mellékletben a képek forrásaival

\section{0. század}

Bordé Katalin: Haiman György, a Kner-örökség továbbvivője = Szabolcs-Szatmár-Beregi Szle (49.) 2014. 3. 72-81. ill.

ERDÉsz Ádám: A betű mủvésze - a betủ tudósa. Haiman György pályája = A huszadik század mezsgyéjén... 13-73. ill.
FARKAS Judit Antónia: Nyomdászattól az alkalmazott grafikáig. Biró Miklós pályaképe $=$ MKsz (130.) 2014. 1. 66-84.

Simon Melinda: 20. századi magyar tiposzignetek $=$ MG (58.) 2014. 1. 74-79. ill.

\section{Könyvmúvészet, illusztráció, ex libris}

BASICs Beatrix: Illumináció, illusztráció, reprodukció - kép és szöveg viszonya a 19. század második felének magyarországi folyóirat illusztrációjában = Olvasható kép, látható szöveg / szerk. LAKNER Lajos. Debrecen: Déri Múz., 2014. 17-23.

Boncz Hajnalka: „Az asszony csendben tanuljon, teljes alázatossággal." Szűz Mária és Szent Anna müveltségének megjelenítése a képzőművészetben $=$ A zsoltártól a rózsaszín regényig... 179-191. ill.

BoreCzKy Anna: Széchényi Ferenc hóráskönyve és a 16. század eleji flamand könyvfestészet $=$ Források és hagyományképek... 110-124. ill.

A tanulmány tárgya az Országos Széchényi Könyvtárban őrzött Cod. lat. 205-ös jelzetü gent-brüggei kódex

CSOBÁn Endre Attila: A „lumen divinum” szimbolikája két 17. századi díszcímlapon $=$ Források és hagyományképek... 125-139. ill.

FARKAS Judit Antónia: Könyvművészet és bibliofília a két világháború között $=\mathrm{KF}$ (24.) 2014. 3. 345-355.

FARKAS Zsuzsa: A fényképre támaszkodó grafika. Adatok a fényképek alapján készült fametszetek köréből = Ars Hungarica (40.) 2014. 2. Sokszorosított grafika. 208-222. ill.

FARKAS Zsuzsa: „Rés a pajzson” A Ferenc József csatorna ábrázolásainak forrásai $=$ Képes világ... 167-190. ill.

FRISNYÁK Zsuzsa: A vasúti ábrázolások forrásértéke, 1854-1890 = Képes világ. .. 145-158. ill.

Hessky Orsolya: Faragó József múvészeti karikatúrái a Borsszem Jankóban = Képes világ... 239-248. ill.

Horváth Hilda: Haiman György, a tipográfus művészi pályája $=$ A huszadik század mezsgyéjén... 87-156. ill. 
HoRVÁth Hilda: Falus Elek (1884-1950), a könyvtervező = MIparműv (21.) 2014. 10. 16-20. ill.

A huszadik század mezsgyéjén. Haiman György (1914-1996) születésének 100. évfordulója emlékére / összeáll. FüZESNÉ HudÁk Julianna, Haiman Ágnes. Gyomaendrőd: Kner Múz. és Kv. Alapítvány, 2014. 246 p. ill.

KaTONA Anikó: Populáris képek: a sajtóillusztráció és a plakát. Mediális különbségek, továbbélő képi sémák = Képes világ... 379397. ill.

„Képes világ”. Tudományos konferencia a 19. századi magyarországi illusztrált sajtóról. A Budapesti Történeti Múzeum és az Országos Széchényi Könyvtár közös rendezvénye / szerk. Szvoboda Dománszky Gabriella. Bp.: BTM-OSZK, 2014. 399 p. ill. (Tanulmányok Budapest múltjából; 39.)

KÉPIRó Ágnes: Korlenyomatok Kass János Tragédia-illusztrációiban $=$ XXI. Madách Szimpózium. Kecskemét, 2013. április 20.-Szeged, 2013. szeptember 20-21. / szerk. BENE Kálmán és MÁté Zsuzsanna. Szeged-Balassagyarmat: Madách Irod. Társ., 2014. 176-186. ill.

Kerny Terézia: Árpád-házi Szent Margit alakja egy XV. századi fametszeten $=$ A zsoltártól a rózsaszín regényig... 65-69.

KöNCZEY Elemér: Bánffy Miklós, az eklektikus grafikus = Bánffy Miklós-emlékkonferencia. 2013. december 18. / szerk. PAPP Endre. Bp.: MMA, 2014. 231-240. ill.

MAczó Péter: Haiman 100 jubileum. Kiállítás és könyvbemutató a Petőfi Irodalmi Múzeumban $=$ MG (58.) 2014. 3. 60-65. ill.

A magyar ex libris 100 éve. Gyüjtemények kiállítása. Katalógus / szerk., bev. VASNÉ TóTH Kornélia. Bp.: KBK Grafikagyüjtő és Müvel. Egyes., 2014. 20 p. ill.

A vándorkiállítást 2014-ben rendezték

NAGY Katalin: „Nézz a képre, halld meg dalom”. Kép és szöveg a képmutogató énekek tükrében. Egy müfaj újraírása = Képes világ... 31-40. ill.

Persovits József: Kner-könyv. A könyvmüvészet mesterei. Bp.: Optima Téka, 2014. 119 p. ill. (Nyomdász könyvtár)
RÉvÉsz Emese: A „magyar régészeti festészet úttörője": Vizkelety Béla, 1825-1864 = Képes világ... 331-378. ill.

RÉvÉsz Emese: Csók István irodalmi illusztrációi a századfordulón $=$ Ars Hungarica (40.) 2014. 2. Sokszorosított grafika. 223245. ill.

SAS Péter: Kós Károly grafikai és könyvmüvészete $=$ Kós Károly-emlékkonferencia. 2013. december 13. / szerk. DÉvÉNYI Sándor. Bp.: MMA, 2014. 71-86. ill.

Somogyi Etelka - PAp Ágnes: „Szentségtörés a csúnya könyv" = Mercurius 2014. 37-38.

TATAI-Baltă, Cornel: Ioaniţiu Endrédi 18. századi balázsfalvi fametsző az európai bibliográfiában = Ars Hungarica (40.) 2014. 2. Sokszorosított grafika. 185-193. ill.

TATAY, Anca Elisabeta: A budai román nyomda néhány 19. század eleji könyvillusztrációjának előképe $=$ Ars Hungarica (40.) 2014. 2 . Sokszorosított grafika. 194-206. ill.

Tomsics Emőke: Lehetőség és kényszer. A fotográfia a nyomtatott képek világában Magyarországon az 1880-as évek előtt = Képes világ... 191-214. ill.

VARGA Emőke: „Ábrázolattal fölvilágosított” irodalom. A Vasárnapi Ujság illusztrációiról = Képes világ... 17-30. ill.

VASNÉ TóTH Kornélia: Kultúrtájak. A magyar világörökség, emlékhelyeink ex libriseken = Tér(v)iszonyok és térkép(zet)ek / szerk. Bíró Csilla, Visy Beatrix. Bp.: Bibl. Nationalis Hungariae-Gondolat, 2014. 190-220. ill. (Bibliotheca scientiae \& artis)

\section{Kisnyomtatványok}

BÁNFI Szilvia - Ecsedy Judit, V.: Plakátalakú nyomtatványok a régi kolozsvári nyomdákból = MG (58.) 2014. 3. 75-79.

A kolozsvári Akadémiai Könyvtárban őrzött dokumentumokról

Heltai János: A hitelesség narratívája az Extractus Brevis (1675) címü röpiratban. Adalékok az 1674. évi gályarabper publicisztikájához $=$ Források és hagyományképek... 20-30. ill. 
KNAPP Éva: Ismeretlen nagyszombati áhítati nyomtatványok a XVII-XVIII. századból = Magyar Sion (8.) 2014. 2. 155-161. ill.

KNAPP Éva: Ismeretlen nagyszombati nyomtatványok $(1661,1745$ körül, 1758) $=\mathrm{MKsz}$ (130.) 2014. 2. 281-287. ill.

KovÁCs Eszter: Cseh nyelvü beszámoló a tolnai csatáról = Források és hagyományképek... 53-60. ill.

Az OSZK Régi Nyomtatványok Tárában örzött Röpl. 422a jelzetű dokumentumról

Seláf Levente - Tóvizi Ágnes: Ismeretlen illusztrált röplap a mohácsi csatáról $=\mathrm{MKsz}$ (130.) 2014. 2. 261-271. ill.

A bambergi Staatsbibliothekban őrzött VI Ba 129 jelzetű dokumentumról. A röplapon szereplő szöveg átírásának közlésével

\section{Térképészet}

GulYÁs Zoltán: A szentpétervári kéziratos Reguly-térkép modern kartográfiai feldolgozása = GeodKart (66.) 2014. 5/6. 12-17. ill.

JANKÓ Annamária: Az első világháborúban használt topográfiai térképek $=$ HK (127.) 2014. 3. 778-792.

KLINGHAMMER István: Tabulák a magyar térképírás történetéböl = MTud (175.) 2014. 10. 1203-1210. ill.

LAKATos Bálint: Lázár deák Tabula Hungariaejának (1528) helyrajza és a késő középkori úthálózat $=$ Archivariorum historicorumque magistra. Történeti tanulmányok Bak Borbála tanárnő 70. születésnapjára / szerk. KÁDÁr Zsófia, LAKatos Bálint, ZARNócZKI Áron. Bp.: M. Levéltárosok Egyes., 2013. 103-128. ill.

Mikesy Gábor: A korai kataszteri térképezés névanyagát befolyásoló utasítások, rendeletek = Helynévtörténeti Tanulmányok (10.) 2014. 103-117.

PÁlyı Zsófia Kata: A kataszteri térképek 1869. évi jelkulcsa = Catastrum (1.) 2014. 3. 1923. ill.

PliHÁL Katalin: Johannes Honterus Chorographia Transylvaniae Sybembürgen címü térképeinek kiadástörténet áttekintése. [1-2.]
$=$ GeodKart (66.) 2014. 1. rész: 9/10. 7-14. ill.; 2. rész: 11/12. 11-18. ill.

Suba János: Partium ábrázolása a történelmi atlaszokban = Közép-Európai Közl (7.) 2014. 3/4=26/27. 41-49.

A Hadtörténeti Térképtár gyüjteményében örzött atlaszokról

TÖRÖK Enikő: Krokik, avagy kataszteri térképvázlatok= Catastrum (1.) 2014. 1.26-29. ill.

\section{Papír}

HorVÁth József - KüNSTLERNÉ VIRÁG Éva: Vízjeltörténeti érdekesség Misztótfalusi Kis Miklós levelén $=$ Turul (87.) 2014. 1. 30-31.ill.

Pelbákt Jenő: Adatok Ochtina papírmalom címer-vízjeleihez = MVízjel (12.) 2014. 27. 47-50. ill.

Pelbárt Jenő: Bazin papírmalom korai vízjele, 1612 = MVízjel (12.) 2014. 28. 45-47.

Pelbárt Jenő: A Berényi-család címer-vízjele. Kokova-2. papírmalom vízjelei között $=$ MVízjel (12.) 2014. 26. 20. ill.

Pelbárt Jenő: Boronás papírmalom Eszterházy címer-vízjele, 1780 = MVízjel (12.) 2014. 28. 49-50. ill.

PelbáRt Jenő: Dobsina-2. papírmalom újabb, koronás magyar címer-vízjele, $1752=$ MVízjel (12.) 2014. 28. 44. ill.

PelbÁRt Jenő: Az első magyar nyelvü növényhatározó, a Magyar Füvész Könyv vízjelei, 1807 = MVízjel (12.) 2014. 26. 11-12. ill.

PelbÁRt Jenő: EL-papírok angyal-vízjele, 1893. = MVízjel (12.) 2014. 26. 5-6. ill.

A stuttgarti Eugen Lemppenau levélborítékés papírfeldolgozógyár angyal-vízjelének ismertetése, amelynek több típusa a Magyar Királyságban is forgalomban volt

Pelbárt Jenő: Gartner János György csillagos-bojtos postakürt-vízjelei, 1784-1820 = MVízjel (12.) 2014. 28. 13-14. ill.

PelbáRt Jenő: Görgény-2. papírmalom koronás-pajzsos postakürt-vízjele, $1787=$ MVízjel (12.) 2014. 28. 15-16. ill.

Pelbárt Jenő: A háromszáz éves Dobsina-2. papírmalom (1714-2014) = MVízjel (12.) 2014. 27. 3-22. ill. 
PelbáRt Jenő: A Heltai-biblia magyar és lengyel vízjelei, 1551 = MVízjel (12.) 2014. 28. 7-12. ill.

Pelbárt Jenő: A híres Tizenkét Tsillagú Korona krúdájának magyar vízjelei, $1769=$ MVízjel (12.) 2014. 27. 37-46. ill.

Pelbárt Jenő: Klimó György püspök pécsi címer-vízjelének új alakja 1786-ból = MVízjel (12.) 2014. 26. 7-8. ill.

PelbáRt Jenő: Kossuth név-vízjel, 1906 = MVízjel (12.) 2014. 26. 3-4. ill.

Pelbárt Jenő: Krisztogramok a filigranológiában = MVízjel (12.) 2014. 26. 21-34. ill.

Pelbárt Jenő: Miramare-vízjel, 1906 = MVízjel (12.) 2014. 27. 33-34. ill.

PelbáRt Jenő: Nagyszeben papírmalom XVIII. századi címer-vízjele = MVízjel (12.) 2014. 28. 48. ill.

Pelbárt Jenő: Ranzanus Epitome rerum Hungaricarum müvének magyar vízjelei, 1746 = MVízjel (12.) 2014. 28. 17-20. ill.

Pelbárt Jenő: Rimakokava papírmalom kiskancelláriai papíralakjának vízjelpárja, 1743 = MVízjel (12.) 2014. 26. 46. ill.

Pelbárt Jenő: Sajószentpéter papírmalom új vízjelpárja, 1833 = MVízjel (12.) 2014. 28. 32. ill.

Pelbárt Jenő: A Sonora Tuba krúda-töredékeinek körmöci vízjeleiről, 1755 = MVízjel (12.) 2014. 28. 25-31. ill.

Pelbárt Jenő: Spilemberg István szomorú levelének vízjele, 1803 = MVízjel (12.) 2014. 26. 9-10. ill.

Pelbárt Jenő: Wenko Oszwald két, emberalakos vízjele $=$ MVízjel (12.) 2014. 28. 33-34. ill.

Pelbárt Jenő: A Zay család címer-vízjel alakváltozatai Kisszlatina papírmalom vízjelei között (1727-1772) = MVízjel (12.) 2014. 28. 21-24. ill.

Pelbárt Jenő - Buncsák Katalin Julianna: Stempel Papier, illetékpapír-vízjel, 1847 = MVízjel (12.) 2014. 26. 49-50. ill.

Pelbárt Jenő - Mór György: Az illoki mesterek céhlevelének vízjelpárja, 1830= MVízjel (12.) 2014. 27. 31-32. ill.

PelbÁrt Jenő - Zombori Lajos: Állat-vízjeleink filigranológiai-taxonómiai összefüggései = MVízjel (12.) 2014. 27. 23--30. ill.
Pelbárt Szilvia: Escorial Bond-vízjel, 1912 = MVízjel (12.) 2014. 27. 35-36. ill.

\section{Könyvkötés-történet}

Mıкó Árpád: Az Egyetemi Könyvtár Dantekódexének (Cod. Ital. 1.) eredeti kötéséről. Henszlmann Imre kiadatlan feljegyzése = MüvtörtÉrt (63.) 2014. 2. 397-400. ill.

Tо́тн Zsuzsanna: Kötéstörténeti kuriózum a Magyar Asszonyok Könyvtárából = Mercurius 2014. 39-40. ill.

\section{Könyvkereskedelem, -terjesztés}

PogÁnY György: A Lampel Róbert (Wodianer F. és Fiai) Könyvkiadó és az oktatásügy a XIXXX. század fordulóján $=\mathrm{KN}$ (16.) 2014. 4. 54-71.

Rózsafalvi Zsuzsanna: „A múzsák versenytársa az ipar”. Az Üllői úti Révai Könyvesház és megépítésének előzményei = Tér(v)iszonyok és térkép(zet)ek / szerk. Bíró Csilla, VIsY Beatrix. Bp.: Bibl. Nationalis Hungariae-Gondolat, 2014. 146-156. ill. (Bibliotheca scientiae \& artis)

\section{Kiadástörténet}

16. század

BÁNFI Szilvia: Az 1570. évi sajtópolémia nyomtatott, példányból eddig nem ismeretes református vitatéziseiről = MKsz (130.) 2014. 2. 272-276. ill.

A wrocławi Ossolińskich gyüjteményben őrzött dokumentumról, RMNy 281

Busdosó Klaudia Erzsébet: A Kolozsvári Arithmetika $=$ Interdiszciplináris pedagógia és a fenntartható fejlődés. A VIII. Kiss Árpád Emlékkonferencia előadásainak szerkesztett változata. Debrecen, 2013. szeptember 6-7. / szerk. BudA András, Kiss Endre. Debrecen: DE Neveléstud. Int., 2014. 140151. ill. 
Dalloul Zaynab: Bernardino Guerralda és a Mediciek történetének könyve $=$ MKsz (130.) 2014. 3. 309-320.

Az OSZK Régi Nyomtatványok Tárában örzött dokumentumról

IMre Mihály: Wilhelm Dilich 1600-ban megjelent hesseni magyar krónikája $=$,Szirt a habok közt”. Tanulmányok Imre László 70. születésnapjára / szerk. BÉNYEI Péter, Gönczy Monika, S. Varga Pál. Debrecen: Debreceni Egy. K., 2014. 59-71. ill.

\section{6-17. század}

HEvesi Andrea: Újfalvi Imre: egy protestáns értelmiségi karrier a 16-17. század fordulóján = Értelmiségi karriertörténetek, kapcsolathálók, írócsoportosulások / szerk. BIRÓ Annamária, BoKA László. Nagyvárad: Partium-Bp.: Reciti, 2014. 31-39.

IMRE Mihály: A kulturális emlékezet forrásai, jellemzői, rétegzettsége Szenci Molnár Albert munkásságában = Certamen I.... 49-66.

KóNYA Annamária: Az első szlovák egyházi könyvek és jelentőségük a szlovák reformátusok történetében $=$ Egyház és történelem. Tanulmányok az egyház életéröl és történelméről / szerk. LÉvAI Attila. Szentendre: Tillinger P. Múhelye, 2013. 159-171.

PÉTER Krisztina: A periodikus sajtó előfutárai. A Messrelationok $=$ KoraújkorÁSZ. Koraújkor-történettel foglalkozó doktoranduszok tanulmányai / szerk. KÁDÁr Zsófia, KöKÉNYesi Zsolt, Mitropulos Anna Diána. Bp.: ELTE BTK Törttud. Doktori Isk., 2014. 71-88.

\section{7. század}

Józsa András: Tófői Zsófi (Toffei Sofia) 1692ben Marosvásárhelyen szerkesztett szakácskönyve $=$ Korunk (Cluj) (25.) 2014. 3. 8187. ill.

KNAPP Éva: Martin von Cochem Magyarországon. Zebegény: Borda Antikvárium, 20141. rész: Mennyei követek, Len kötelecske, Az két atyafi szent szüzek Gertrudis és Mechtildis imádságos könyve. 2014. 119 p.
(Régi magyarországi vallásos nyomtatványok; 1.)

KovÁcs Eszter: A Makula nélkül való tükör cseh forrásai. Bp.: MTA-PPKE Barokk Irod. és Lelkiség Kutatócsop., 2014. 156 p. (Pázmány irodalmi műhely. Lelkiségtörténeti tanulmányok; 9.)

TASI Réka: Mutatók és kompiláció 17-18. századi katolikus prédikációgyüjteményekben = Közkincs. Tanulmányok a régi magyarországi prédikációk kompilációjáról / szerk. MACZÁK Ibolya. Bp.: MTA-PPKE Barokk Irod. és Lelkiség Kutatócsop., 2014. 111-123.

VADAS András: „Az elmúlt esztendőben fordítottam magyar nyelvre deákul íratott Thuróczy János históriás könyvét”. Egy ismeretlen muravidéki nemes és a Thuróczy-krónika = MKsz (130.) 2014. 2. 180-203.

Mellékletben a tanulmányban hivatkozott levelek közlésével

\section{8. század}

Ecsedy Judit, V.: Bod Péter müveinek kiadástörténetéhez. Hamis évmegjelölésủ változatok = MKsz (130.) 2014. 1. 10-29. ill.

ÉDER Zoltán: Sajnovics Demonstratiójának első recenziója. „Viennensis Recensitor opusculi mei Hafniae editi” = MNyelv (110.) 2014. 1. 85-94. ill.

Hermán M. János: Tatai (Csirke) Ferenc, ,V. D. M., vir est optimus". Tatai Ferenc lelkipásztor müveiről, alapítványáról, hazai és svájci kapcsolatairól; továbbá 1742-es levele Beck professzorhoz és 1755-ös levele Szentgallenbe. Temetési beszéde Domokos Márton debreceni föbíró fölött = Református Szle (107.) 2014. 2. 193-234.

PÁLfI József: Egy polihisztor karácsonyi ajándéka $=$ Egyház és történelem. Tanulmányok az egyház életéröl és történelméröl / szerk. LÉvAI Attila. Szentendre: Tillinger P. Mühelye, 2013. 227-247.

То́тн Gergely: Meddig terjed Magyarország? Történelmi jogok és politikai realitások küzdelme Bél Mátyás Notitiájában = Archivariorum historicorumque magistra. Történeti tanulmányok Bak Borbála tanárnő 
70. születésnapjára / szerk. KÁDÁr Zsófia, LAKatos Bálint, ZarnóczKi Áron. Bp.: M. Levéltárosok Egyes., 2013. 143-163.

\section{8-19. század}

Bodrogi Ferenc Máté: Dologi hurok a szellemi müveleten: a szöveg mint nyomtatott termék. A Kazinczy Ferencz' Munkáji: Szép Literatúra kiadástörténetéhez $=$ Textológia... 43-56. ill.

GranaszTór Olga: Kazinczy Ferenc, avagy Abafi Lajos Magyar Pantheonja. Egy Kazinczy-kiadás előkészületei $=$ Textológia... 75-92.

19. század

GAzDA István: Az akadémiai könyvkiadás és könyvszerkesztés reformkori történetéből = KF (24.) 2014. 2. 194-198.

19-20. század

Frauhammer Krisztina: Imakönyvek. Feltáratlan források = Vallás, egyén, társadalom / szerk. Barna Gábor, Kerekes Ibolya. Szeged: SZTE BTK Néprajzi és Kult. Antropológiai Tansz., 2014. 67-83.

Szelestei NAGY László: A hívek szentmiseimádságai a kora újkorban $=$ Misztika a 1618. századi Magyarországon / szerk. BoGÁR Judit. Piliscsaba: PPKE BTK, 2013. 249261. ill.

TöLGYESI József: Veszprém vármegyei tankönyvszerzők és tankönyvek a polgári korban, 1867-1944 = KN (16.) 2014. 4. 72-87.

20. század

Csima Ferenc: A hazai lelkiségi mozgalmak könyvkiadása 1990-től napjainkig = Magyar Sion (8.) 2014. 1. 105-118.

Csima Ferenc: A magyarországi bencések könyvkiadása 1990 után $=$ MKsz (130.) 2014. 1 . 101-109.

Mózes Huba: 90 éve alakult az Erdélyi Szépmíves Céh = Hitel (27.) 2014. 10. Archaikus mosoly - posztmodern vigyor. 91-94.
PARÁDi Andrea: Az Aranysárkány kéziratának ismertetése és közlési elvei = Irodalomismeret 2014. 1. 89-98. ill.

Az MTA Kézirattárában örzött Ms 4615/ 1-49 jelzetü dokumentumokról

SCHILLER Erzsébet: A Mai orosz dekameron szerkesztése, 1935-1936 = ItK (118.) 2014. 4. 547-560.

\section{Sajtótörténet}

16-17. század

HANNY Erzsébet: Török háborúk, spanyol hírek. A hír útja és olvasója a Spanyol Királyságban a kora újkorban $=$ Világtörténet $(4=36$. $)$ 2014. 1. 125-137. ill.

18. század

Antal Alexandra: A bécsi Magyar Hírmondó (1789-1803) mecénási hálózata = It (95.) 2014. 4. 432-448.

Antal Alexandra: A bécsi Magyar Hírmondó (1789-1803) szerkesztői hálózata = ItK (118.) 2014. 1. 99-117.

\section{9. század}

BÁRÁNY Zsófia: Lonovics József szentszéki delegációjának hazai sajtóvisszhangja. ,Vallási catechismusunk van, polgári nincs!" = Médiakutató (15.) 2014. 2. 29-36.

BAsics Beatrix: „,...elmélkedésre hívó jelenet az élet- és történelemből”. Eseményábrázolások a 19. századi folyóirat-illusztrációkon = Képes világ... 159-166. ill.

Bódy-MÁrkus Rozália: A Sonntags Zeitung. Illusztrált német nyelvü hetilap a Vasárnapi Ujság szomszédságában = Képes világ... 65-80. ill.

Buzinkay Géza: Szerzői levelek a Családi Lapok szerkesztőjéhez, Ney Ferenchez, 1853-1855 = MKsz (130.) 2014. 4. 486490.

A tanulmányban említett levelek szövegének közlésével 
FeHÉr Katalin: Az erdélyi sajtó és a nevelés a 19. század első felében = Magiszter (12.) 2014. 4. 104-116.

FrIEd István: Jókai Mór 1854-ben és 1904-ben = Tiszatáj (68.) 2014. 5. 96-109.

A Vasárnapi Ujságnál végzett tevékenységéről

Gracza Tünde: „,..’s által fogja a' haza látni, hogy bizonnyal hasznára élt". 210 éve jelent meg az Orvosi, és Gazdasági Tudósítások = Pedagógia, oktatás, könyvtár... 301-318. ill.

GYÁNTI István: „Baranya vármegye és a Dunántúl első napilapja". A Pécsi Napló indulása és fejlődése a századfordulóig, 1892-1902 = Öttorony vonzásában / szerk. KerEKEs Imre. Pécs: Csorba Gy. Kvt., 2014. 58-75. ill.

KorB Angéla: Az 1840-es évek német nyelvü sajtója Pest-Budán = Gazdaság és kultúra. A nemzetiségek gazdasági és kulturális tevékenysége Magyarországon a 19. és 20. században / szerk. MenyHáRt Krisztina. Bp.: Bolgár Kult. Fórum; Kecskemét: Bolgár Nemzetiségi Önkormányzat, 2014. 181-190.

LANDGRAF Ildikó: Átjárás a regiszterek között. Jókai Mór képes szórakoztató lapjai = A sajtó kultúraközvetítő... 9-20.

LANDGRAF Ildikó: „Ez csak úgy vót megcsinálva”. A képes sajtó hatása Rudolf trónörökös folklórjára = Képes világ... 289-304. ill.

LIPTÁK Dorottya: „Kép és írás”, képírás az európai és a magyar illusztrált sajtóban. Néhány bevezető gondolat egy elfeledett történet tanulmányozásához = Képes világ... 9-16.

Losonczi Eszter: A ,zsidó” ábrázolása a 19. század második felének magyar élclapjaiban = Képes világ... 277-288. ill.

Mader Béla: A Tudományos Gyüjtemény és Vörösmarty. Reformkori tudományos folyóiratunk történetéből $=$ Pedagógia, oktatás, könyvtár... 343-360.

Mátyás Melinda - Szluka Péter - Vasas Lívia: Az idézés kezdete és formai jellegzetességeinek változása a legkorábbi orvosi folyóiratok tükrében $=$ KKK (23.) 2014. 6 . 30-41. ill.

PAP Dávid Zoltán: A pécsi újságírás első évtizedei, 1832-1862 = Öttorony vonzásában
/ szerk. Kerekes Imre. Pécs: Csorba Gy. Kvt., 2014. 39-57. ill.

PAPP Gábor György: Önkép alkotás és régiótudat. Magyarország, az európai építészeti diskurzus és a 19. századi szaksajtó = Képes világ... 305-316. ill.

SCHMIDT Anikó: A Kataszteri Kalauz. Gondolatok az első földmérési folyóiratról $=\mathrm{Ca}$ tastrum (1.) 2014. 1. 20-25. ill.

SIRATó Ildikó: Sokszínű ábrázolatok a sajtó alatt. A színház képei az újságlapokon = Képes világ... 89-104. ill.

STEINMACHER Kornélia: Élclapok a kiegyezés idejében. 1865-1867 = Textológia... 237-254. ill.

Szvoboda DomÁnszky Gabriella: Képzőmüvészeti reprodukciók a sajtóban a 19. század első felében = Képes világ. .. 41-64. ill.

TASNÁDI Kata: Sajtó és fotó a sajtófotó előtt. A nyomtatott fotók megjelenése a magyar képes lapokban az 1880-as években = Médiakutató (15.) 2014. 4. 35-48.

THuRóczy Gergely: Élclapok mostohagyermeke. Jankó János és a magyar képregény kezdetei a Bolond Miskában $=$ Képes világ... 249-276. ill.

То́тн Benedek: A Wochenplauderei mint beszédmód. Egy lehetséges megközelítés $=\mathrm{MKsz}$ (130.) 2014. 4. 452-471.

UjvÁRI Hedvig: A pest-budai német sajtó jelentősége és irodalomközvetítő szerepe a kiegyezés után $=$ A sajtó kultúraközvetítő $\ldots$. $37-50$.

\section{9-20. század}

ÁBrAHÁm Barna: Szlovák sajtó és nemzetépítés a dualizmus korában = A sajtó kultúraközvetítő... 51-67.

BuZINKAY Géza: Világkiállítások papíron. A képes családi hetilapok $=$ Képes világ... 8188. ill.

FABÓ Edit: Gúny és kritika = Képes világ... 215-238. ill.

Gellér Ferencné: A sajtó közéleti küzdelmei a „Dongó” élclap tükrében $=$ Hajdú - Bihar M. Levtár Évkve (33.) 2014. 223-306.

Hansági Ágnes: Kemény Zsigmond, a Pesti Napló, az „olvasási vágy” és egy drámai 
költemény $=$ Studia litteraria 2014. 3/4. Emlékezet és irodalom. Kemény Zsigmond 1814-2014. 25-50.

Ко́түuк Erzsébet: A Szemészet című folyóirat 150 éve = Orvostört. Közl (60.) 2014. $1 / 4 .=226 / 229$. 133-157.

KöBÁNYAI János: Szétszálazás és újraszövés. A Mult és Jövő, a Nyugat és a modern zsidó kultúra megteremtése. Bp.: Osiris, 2014. 430 p. ill.

MARosi NAGY Lajos: Mit mondhatunk a baptista sajtó napján? = Szolgatárs (23.) 2014. 2. 35-40. ill.

A sajtó kultúraközvetítő szerepe, 1867-1945. Tanulmányok / szerk. PAÁL Vince. Bp.: MTA BTK, 2014. 111 p. (Médiatudományi könyvek)

A Budapesten, 2013. máj. 23-án rendezett konferencia szerkesztett anyaga

SubA László: A pénzügyőrségi sajtó kezdetei $=$ Hadtud Szle [elektr. dok.] (7.) 2014. 1 . 113-120.

Elektr. hely és hozzáférés: <http://uni-nke. hu/downloads/kutatas/folyoiratok/hadtudomanyi_szemle/szamok/2014/2014_ 1/2014_1_tt_subal.pdf

20. század

AgÁRDI Péter: Mozaikkocka a magyar sajtó legújabb kori történetéből. A Tekintet negyedszázada = Pedagógia, oktatás, könyvtár... 287-299.

BALASSA Zoltán: A cenzúra története Csehszlovákiában 1918-1992. A magyar sajtószabadság lehetőségei. „Az újságírók tolla a legkönnyebben hajlítható" = A határon túli magyar sajtó... 11-56.

BENCE Lajos: A sajtó- és szólásszabadság, avagy a muravidéki magyarság küzdelmei a XX. században = A határon túli magyar sajtó... 279-313.

Bolemant Lilla: Női szempontok a (cseh)szlovákiai magyar irodalom és újságírás tükrében, 1919-1938 = Fórum Társtud. Szle (16.) 2014. 1. 157-167.

BudA Attila: Néhány gondolat Lengyel András A Nyugat iskolájának elvetélt terve (1918) című írásához = MKsz (130.) 2014. 1. 94 100.

Czeferner Dóra: „Kávéházakban, klubokban, olvasókörökben kérjük A Nő és a Társadalom lapot!" Egy folyóirat a nők egyenjogúságáért = Médiakutató (15.) 2014. 2. 49-61.

DANYI Gábor: Az ajándékozás müvészete. A Szétfolyóirat terjesztési modellje a szamizdat jelenségének szemszögéből = It (95.) 2014. 1 . 48-67.

DÉsI János: Lévai Jenő és a zsidóság = Múlt és Jövő (24.) 2014. 2. A szó elszáll, az emlékmü itt marad. 37-48. ill.

GYöRFFY Gábor: A magyar nyelvü sajtó és sajtószabadság története Romániában 19181989 = A határon túli magyar sajtó... 97164.

A határon túli magyar sajtó Trianontól a XX. század végéig. Fejezetek a magyar sajtószabadság történetéből / szerk. APró István, PAÁL Vince. Bp.: Médiatud. Int., 2014. 321 p. (Médiatudományi könyvtár)

HoRvÁTH István: A Magyar Csillag végjátéka és a Nyugat Kiadó megmentési kísérlete. Gellért Oszkár és Illyés Gyula levelezése 1944 nyarán = Múlt és Jövő (24.) 2014. 4. Az eltünt emlékezet nyomában. 55-62.

HoRvÁTH István: Szerkesztő a vészkorszakban. Illyés Gyula és a Magyar Csillag. Bp.: Múlt és Jövő K., 2014. 255 p. ill.

Izsák Anikó Borbála: Éhezik? Fázik? Egyen csokoládét, öblítsen Diana sósborszesszel! A Népszavában megjelent hirdetések 1907 és 1932 között = Médiakutató (15.) 2014. 3. 51-64.

KIss Réka: Identitásépítés a magyar református sajtóban a XX. század első felében. A Református Figyelő példája = A sajtó kultúraközvetítő... 81-98.

KLestenitz Tibor: A katolikus sajtó mint az új vallási kultúra közvetítője a XX. század elején = A sajtó kultúraközvetítő... 69-80.

KolLARITs Krisztina: „Csak szétszórt őrszemek vagyunk...”. Tanulmányok a Napkeletről. Vasszilvágy: M. Nyugat Kvk., 2014. 259 p.

KovÁcs Elemér: A magyar nyelvü sajtó és sajtószabadság története Kárpátalján 1918-1989 = A határon túli magyar sajtó... 57-96. 
Lengyel András: Az induló Az Est piaci „bevezetésének" egyik összefüggéséről és technikájáról = Jelenkor (57.) 2014. 9. 986-994.

Lengyel András: A Népszavától a Progreso y Culturáig. Barna Sándor (1887-1952) „könyves” pályája = Múlt és Jövő (24.) 2014. 2. A szó elszáll, az emlékmü itt marad. 101-126.

MÁk Ferenc: A horvátországi magyar sajtó 1914-1989 = A határon túli magyar sajtó... 237-277.

Mák Ferenc: Magyar sajtó a Délvidéken 19141989 = A határon túli magyar sajtó... 164236.

MolnÁr Szilvia, Sz.: A Magyar Mühely a Kádár-rendszerben = MMühely 2014. 1=167. 32-40.

NAGY Gábor: A magyar sajtó politika a koalíciós időszakban, 1944-1948. Sajtótörténeti vázlat $=$ Századok (148.) 2014. 6. 14651491.

PAÁL Vince: A burgenlandi magyar sajtó 19201989 = A határon túli magyar sajtó... 315-321.

Pogány György: A Könyvtári Figyelő hatvan évfolyama. 1. rész, 1955-1968; 2. rész, 1969$2014=\mathrm{KF}$ (24.) 2014. 1. rész: 3. 331-344.; 2. rész: 4. 493-513.

Róbert Péter: Nehéz idők... A cionista sajtó történeti emlékei Magyarországon a II. világháború alatt. Bp.: Mo. Cionista Szövets., 2014. 245 p. ill. (Bethlen téri füzetek)

Ruszoly József: „Rohanunk a forradalomba”. Köztársasági pörök Szegeden 1911-1915 $(1919)=$ Szeged (26.) 2014. 10. 5-15. ill. SzABó Zsolt: Kós Károly publicisztikája = Kós Károly-emlékkonferencia. 2013. december 13. / szerk. DÉvénYI Sándor. Bp.: MMA, 2014. 118-128.

SzÉCHENyi Ágnes: Schöpflin Aladár útja a modernséghez. A pályakezdés orgánuma: a Vasárnapi Újság. = A sajtó kultúraközvetítő... 21-36.

TAKÁCS Róbert: Sport és újságírás Bern után = Múltunk (59.) 2014. 2. 189-216.

UJVÁRY Gábor: „A százkezü ember”. Hegedüs Sándor, a publicista és szakíró $=$ Hegedüs Sándor, a százkezü politikus. Tanulmányok, dokumentumok / szerk. Katona Tamás,
SzÁsz Zoltán. Bp.: Argumentum, 2014. 55142. ill.

VALLASEK Júlia: Balra át! Jékely Zoltán a Világosság „kultúrpolitikusa” = Értelmiségi karriertörténetek, kapcsolathálók, írócsoportosulások / szerk. BiRó Annamária, BOKA László. Nagyvárad: Partium; Bp.: Reciti, 2014. 295-304.

\section{Sajtótermékek mint forrásanyagok}

ALmási Gábor: A Secretissima instructio, 1620. A kora újkori politikai paradigmaváltás egy Bethlen-kori röpirat tükrében. Bp.: ELTE BTK Középkori és Kora Újkori M. Tört. Tansz.-Transylvania Emlékeiért Tud. Egyes., 2014. 233 p. ill.

ANDRÁs Zselyke: Szabó T. Attila nyelvészeti írásai a két világháború közti Erdélyi Múzeumban = Certamen I.... 13-20.

BenKő Zsuzsanna: Katona és Lendvay a Nemzeti színház előtt. Czélkúti Züllich Rudolf: Katona József és Dunaiszky László: Lendvay Márton szobra a korabeli sajtó tükrében = Képes világ... 317-330. ill.

BóDÁn Zsolt: „Békés” antiszemitizmus. A zsidókérdés egy gyulai napilapban az 1930-as évek végén $=$ A holokauszt Békés megyei történeteiből. A Magyar Nemzeti Levéltár 2014. június 12-i, gyulai konferenciáján elhangzott előadások / szerk. ERdész Ádám, KovÁcs Tamás. Gyula: MNL Békés M. Lvt., 2014. 32-54.

Czeferner Dóra: A női munka interpretációja és diskurzusa az osztrák-magyar feminista sajtóban = Diplomácia, emancipáció és egyházpolitika / szerk. ZACHAR Péter Krisztián. Bp.: Heraldika, 2014. 51-153. ill.

Fenyves Katalin: Mi mozog a zöldleveles bokorban? Magyar ,népdalok” jiddis fordítása a Magyar Zsidó Szemlében = Hagyományláncolat és modernitás / GLÄSSER Norbert, ZIMA András. Szeged: Néprajzi és Kult. Antropológiai Tansz., 2014. 187-205. ill.

FöLDVÁRI József: A „zsidó nő” ideje és a hagyomány teremtésének láncolata. Adaptációs stratégiák müködtetése a Múlt és Jövő folyóiratban = Hagyományláncolat és moder- 
nitás / GLÄsSER Norbert, ZIMA András. Szeged: Néprajzi és Kult. Antropológiai Tansz., 2014. 248-258.

GLÄSSER Norbert: Orthodox kóser tömegirodalom? Sajtóviták a zsidó ifjúsági irodalom orthodox és neológ értelmezései körül $=$ Hagyományláncolat és modernitás / GLÄSSER Norbert, Ziмa András. Szeged: Néprajzi és Kult. Antropológiai Tansz., 2014. 217-229. ill.

GLÄsSER Norbert: Találkozás a Szent Igazzal. A magyar nyelvű orthodox zsidó sajtó cádik-képe, 1891-1944. Szeged: Néprajzi és Kult. Antropológiai Tansz., 2014. 374 p. ill. (Szegedi vallási néprajzi könyvtár; 40.). (A vallási kultúrakutatás könyvei; 8.)

GLÄSSER Norbert - ZIMA András: „Olaszország királya háborút üzent”. Az olasz fronton harcoló magyar zsidók a sajtó hasábjain = Szombat (26.) 2014. 6. 13-15.

KARSAI László: A holokausztról szóló információk a magyar sajtóban, 1941-1944 = Századok (148.) 2014. 6. 1365-1374.

KLestenitz Tibor: „A rendes mederben javul a miniszterelnök állapota" A KSV-lapok, az Esti Újság és Gömbös Gyula utódlásának kérdése = Médiakutató (15.) 2014. 2. 87-95.

KÖKÉNY Andrea: Texas korai története a Vasárnapi Újság hasábjain = Aetas (29.) 2014. 2. Amerikai és magyar históriák. 5-27.

NAGY Anikó, B.: Éhhalál képen kívül. Az 1863-as nagy alföldi aszály sajtóképe $=$ Képes világ... 127-144. ill.

NAGY Gábor: Az 1945. júliusi papírbotrány reprezentációja a korabeli politikai sajtóban = Médiakutató (15.) 2014. 2. Sajtó, információ, társadalom. 105-115.

PerÉNYi Roland: Nyomor, bün, deviancia. A nagyváros szociális problémáinak kép(telenség)e a 19-20. századi szociális riportokban $=$ Képes világ... 105-126. ill.

Simon Bernadett: A Millenniumi Újság jelenti ... = Kút (13.) 2014. 1. 93-110.

TAmÁs Ágnes: Megrajzolt hírek. Az olasz egység létrejötte és a magyar függetlenség vágya a korabeli magyar élclapokban $=$ Médiakutató (15.) 2014. 2. 37-48. ill.

TAmÁs Ágnes: Vizuális percepciók a Nagy Háborúról a hatalom szürőin keresztül. A Bors- szem Jankó, a Figaro és a Kladderadatsch rajzainak elemzése $=$ Aetas (29.) 2014. 3. Az első világháború. 59-77. ill.

Turbucz Dávid: Horthy-képek a magyar sajtóban 1945 és 1956 között = Médiakutató (15.) 2014. 4. 25-33.

Turbucz Dávid: A sajtó szerepe a Horthy-kultusz építésében. A politikai hatalom elvárásai a magyar állampolgárokkal szemben = sajtó kultúraközvetítő... 99-111.

VöRös Boldizsár: Történelemhamisítás, propaganda, sajtó. Illés Béla két kitalációja az általa szerkesztett újságokban 1944-1948 között = MKsz (130.) 2014. 4. 472-485.

VöRös László: „A leghazafiasabb magyarok” vagy „egy szabad nemzet”? A szlovákok szociális reprezentációi a magyar sajtóban 1914-1918 között = Kor/ridor (1.) 2014. 3. 25-60.

ZIMA András: „Souvajsz Jeruzsálemben”. A Szentföld modern átértelmezései a magyar nyelvű neológ és cionista sajtóban a 20. század első felében = Hagyományláncolat és modernitás / GLässER Norbert, Zima András. Szeged: Néprajzi és Kult. Antropológiai Tansz., 2014. 88-96.

Zsupos Zoltán: Hirdetmények, színlapok, aprónyomtatványok. Győr, 1848-1849 = Kundmachungen, Theaterzettel, Kleindrucksachen. Raab, 1848-1849. Győr: Rómer F. Műv. és Tört. Múz., 2014. 711 p. ill. (A Rómer Flóris Művészeti és Történeti Múzeum katalógusai; 1.)

\section{Könyvtártörténet}

\section{Több évszázadot érintő munkák}

FAA-Lendvai Erzsébet: A Tihanyi Bencés Apátság és könyvtárának története. A kezdetektől a 18. század végéig = Egyházi, családi és asszonykönyvtárak... 231-290.

KovÁcs Irén: Az Esterházy-gyűjtemény kalendáriumai = Egyházi, családi és asszonykönyvtárak... 291-401.

A Kismartonban 1938 augusztusában megtalálható naptárak jegyzékével 
Magyar könyvtártörténeti kronológia, 996-2007 / összeáll. GERö Gyula; közrem. RÁcz Ágnes. Bp.: OSZK, 2009-

4. köt. 2008-2010, pótlások, javítások 9962007. 2014. 428 p.

\section{7. század}

PogÁnynÉ Rózsa Gabriella: James Kirkwood (1650-1708) tervezete a parókai nyilvános könyvtárak alapítására $=\mathrm{KN}$ (16.) 2014. 2. 31-48.

18. század

PÁkozdi Éva Szilvia: A veszprémi piarista könyvtárak adományozói. 2. Kisovics József kanonok $=$ Veszprémi Szle (16.) 2014. 2=33. 74-86. ill.

„Tudástár - anno". Lexikonok, enciklopédiák a Somogyi-könyvtár régi és ritka gyüjteményében. Kiállítás a Somogyi-könyvtárban, 2014. július 15-október 8. / rend., ism. SzÖKEFALVI-NAGY Erzsébet. Szeged: Somogyi-kvt., 2014. 28 p. ill.

Angol nyelven is

19. század

Csesznegi Viktória: A Zombori Karmelita Rendház régi könyvei $=$ Egyházi, családi és aszszonykönyvtárak... 141-230.

PAPP Csaba István: A tiszaugi református egyház parochiális könyvtárának gyüjteménye = Egyházi, családi és asszonykönyvtárak... 403-469.

SzILÁGYI Mariann: Hungarika-kutatás a Klimo Könyvtárban. A Szepesy-katalógus magyar nyelvű nyomtatványai = Pedagógia, oktatás, könyvtár... 561-574. ill.

\section{9-20. század}

Mák Ferenc: Példányképek a nagy tettekhez. Régi fehértemplomi bibliotékák = KKK (23.) 2014. 2. 37-45.
20. század

BÁNYAI Réka: Az egykori székelykeresztúri unitárius gimnázium könyvtára a Teleki Tékában = Areopolisz (13.) 2013. (2014.) 107-122., 264.

Eltiporva. A vészkorszak és az Országos Széchényi Könyvtár. Az Országos Széchényi Könyvtár kiállítása. 2014. május 28-július 12. Tanulmányok a vészkorszakról és történelmi előzményeiről / szerk. UJVÁRY Gábor. Bp.: OSZK, 2014. 64 p. ill.

EMÖDI András: Könyvtár- és levéltárügy Nagyváradon kényszerek és gyarlóságok tükrében, azaz valóban siralmas váradi krónika, 1944-1987 = Erdélyi Múzeum (Kolozsvár). (75.) 2013. 4. 76-107.

A Nagyváradi Római Kat. Egyházmegyei Levéltárban ôrzött válogatott források betühív közlésével

GrÁBerné Bösze Klára: A Szent Orsolya Rend megtelepedése Budapesten. A budai orsolyiták iskoláinak története 1922-1948 = KN (16.) 2014. 2. 77-94.

KapronCZay Károly: Mozgalmas két évtized. Az Orvostörténeti Könyvtár megalakulása és története = Orvostört. Közl (60.) 2014. $1 / 4 .=226 / 229$. 233-266.

Kolozs Barnabásné: A veszprémi angolkisaszszonyok intézete iskolai könyvtárának (töredék) története $=$ Veszprémi Szle (16.) 2014. 3=34. 48-62.

SonNevend Péter: A sztálini önkényuralom áldozata. A szovjet közkönyvtárak a második világháborúig, 1928-1941. 2. rész: A Krasznij bibliotyekar címü szaklap, 1923-1941 = KF (24.) 2014. 1. 89-112.

SzEBERÉNYI Gábor: Holub József és a Tagányikönyvtár Pécsre kerülése. Egy „vidéki” történészprofesszori egzisztencia lehetőségfeltételei az 1920-as évek elején. 1. közlemény $=$ Per aspera ad astra [elektr. dok.] (1.) 2014. 2. 117-137.

Elektr. hely és hozzáférés: $<$ http://per-aspera. pte.hu/archivum/2-szam-2.html>

Tengely Adrienn: „A jó könyv-levél a jó Istentől". A katolikus hitbuzgalmi társulati könyvtárak a 20. század első felében Pécsett 
= Öttorony vonzásában / szerk. KereKES Imre. Pécs: Csorba Gy. Kvt., 2014. 116-126.

\section{Bibliofília, magánkönyvtárak}

BARANYAI Katalin: Egy asszonykönyvtár a 18. századból. Wesselényi Kata könyvjegyzéke alapján = Egyházi, családi és asszonykönyvtárak... 9-140.

„Néhai M(é)1(tósá)g(o)s gróf Rédey Sigmondné asszony halála után maradott könyvei catalogussa" közlésével

Berecz Ágnes: Ráday Gedeon, a könyvgyüjtő életműve = A Ráday-család a magyar kultúrában. 300 éve született Ráday Gedeon. A 2013. október 10-én megrendezett jubileumi konferencia előadásai / szerk. BERECZ Ágnes. Bp.: Ráday Gyüjtemény, 2014. 9-17.

BognÁR Tímea: Vándorló könyvek. Tulajdonbejegyzések és ex librisek a Pálffy család csépi gyüjteményében = Könyvtár és történet / szerk. Czeglédi László, Verók Attila. Eger: Líceum K., 2014. 47-99.

Függ.: A Pálffyak könyvei, A Siegler-könyvtár könyvei, A Thaly család könyvei, Kiss Dénes és családja könyvei, Batáry Pál könyvei

CsıKós Júlia: Ráday Eszter könyvtára = Certamen I.... 81-89.

Csorba Dávid: Debreceni Ember Pál ellopott és eltünt könyvei $=$ MKsz (130.) 2014. 2. 204-217.

CsORBA Dávid: Debreceni Ember Pál könyvtára =Zempléni Múzsa (14.) 2014. 3. 33-47.

DeÉ NAGY Anikó: A könyvtáralapító Teleki Sámuel és Hollandia = Történetek a mélyföldről. Magyarország és Németalföld kapcsolata a kora újkorban / szerk. BozzAY Réka. Debrecen: Printart-Press, 2014. 296-332.

Mell.: Kézírásos útinapló. II. kötet

DóвÉK Ágnes: Barkóczy Ferenc könyvtárának olasz nyelvü kötetei $=$ MKsz (130.) 2014. 3. 321-335.

Az Esztergomi Főszékesegyh. Kvtban őrzött dokumentumokról

EMőDI András: Egy elfeledett felvilágosodás kori nagyváradi tudóskönyvtár. Rier Ferenc Xavér
(1722-1776) matematikai, természettudományos, hadtudományi és természetbölcseleti tárgyú kötetei $=$ Tanulmányok NagyváradÚjváros megalapításának 300. évfordulója alkalmából (1714-2014) / szerk. EMŐDI András. Nagyvárad: Partium Kiadó, 2014. 69-139.

(Miscellanea historica Varadinensia; 4.)

FARKAS Judit Antónia: Haiman György és a Moholy-Nagy Művészeti Egyetem Könyvtárának Kner-különgyüjteménye $=$ A huszadik század mezsgyéjén... 201-205.

GÁBORJÁNI Szabó Botond: Kazay Sámuel és a Debreceni Kollégium. Egy könyvgyüjtő patikus élete és gyüjteményének sorsa. Fejezet a historia litteraria magyarországi történetéből. Debrecen: Tiszántúli Ref. Egyhker. Gyüjt., 2014. 497 p. ill. (A Tiszántúli Református Egyházkerületi Gyűjtemények kiadványai)

Kolozs Barnabásné: Kisovits József veszprémi apátkanonok 19. századi könyvtára $=$ Veszprémi Szle (16.) 2014. 1=32. 61-68. ill.

KovÁcs Mária: Egy erdélyi magánkönyvtár története. Cserei Mihály könyvgyüjtési és olvasási szokásai = Areopolisz (13.) 2013. (2014.) 9-44., 262-263.

„Könyvim az én fiaim”. Vitkovics Mihály könyvtára / feldolg. és szerk. CsePregr Klára, BOR Kálmán. 2. átd. kiad., átd. KÉGLI Ferenc. Bp.: OSZK-Gondolat, 2014. 332 p. ill. (Nemzeti téka)

MoNOK István: Az arisztokrata könyvtárak rendjének változásai a 17-18. századi Magyarországon = Szőcs Géza 60. Album amicorum / szerk. Gáll Attila. Kolozsvár: Erdélyi Híradó-IJK, 2013. 153-161.

NAGY Anikó: A Magyar Asszonyok Könyvtára. Ismertetés és újabb adalékok $=\mathrm{KF}$ (24.) 2014. 1. 63-70. ill.

NAGY Györgyi: Apponyi Sándor kapcsolata hazai és külföldi antikváriumokkal $=$ Források és hagyományképek... 157-170.

Penke Olga: A gondolatok terjedésének nyílt és rejtett útjai. Bayle, Beccaria, Pascal és Voltaire Péczeli József könyvtárában $=$ MKsz (130.) 2014. 3. 336-352.

VARGA Zita: Gárdonyi Géza könyvtára = „Agyagedénybe zárt Isten-sugár”. In memoriam 
Gárdonyi Géza / szerk. Cs. VARGA István. Bp.: Hungarovox, 2014. 203-216.

Zvara Edina: Esterházy Miklós (1765-1833) herceg, a magyar müvelődés támogatója $=$ MKsz (130.) 2014. 3. 374-381.

\section{Olvasástörténet}

Csorba Dávid: A Sajószentpéteri-család fennmaradt könyvei $=$ Ki nem száradó Patak. Győri István tiszteletére. Tanulmányok / szerk. ENGHY Sándor. Sárospatak-Hernád: Sárospataki Ref. Teol. Akad., 2014. 431447.

FAZAKAS Gergely Tamás: Angol történelem a margón. Szempontok Lewis Bayly Practice of piety magyar, holland és más nyelvü fordításainak értelmezéséhez $=$ Történetek a mélyföldröl. Magyarország és Németalföld kapcsolata a kora újkorban / szerk. BozZAY Réka. Debrecen: Printart-Press, 2014. 344360.

FAZEKAS István: Könyv- és olvasáskultúra a győri egyházmegye papsága körében a XVII. század második felében $=\mathrm{A}$ reform útján. $\mathrm{A}$ katolikus megújulás Nyugat-Magyarországon / Fazekas István. Győr: Győri Egyházm. Lvt., 2014. 147-162.

Hegy Ádám: „Szükségtelen bibliothécák” és folyton csak olvasó lelkészek a Békési Református Egyházmegyében a 18. század végén = Mediárium (8.) 2014. 3. 5-24.

Horváth Györgyi: A passzív olvasó toposza a 18-19. század fordulóján = A mủvészettől a tömegkultúráig / szerk. Olay Csaba, WeIss János. Bp.: L'Harmattan-Könyvpont, 2014. 135-146.

JÁKI László: Diáktársaságok, egyesületek szerepe az irodalom, az olvasás megszerettetésében. Az önképzőkörök előtörténete, 17901848 [elektr. dok.] = Elektronikus KN (16.) 2014. 3 .

Elektr. hely és hozzáférés: <http://olvasas. opkm.hu/portal/felso_menusor/konyv_es neveles/diaktarsasagok_egyesuletek_szerepe_az_irodalom_az_olvasas_megszeretteteseben2>
KALMÁR Anna: Fő́ri könyvtárak, pedagógiai olvasmányok Magyarországon (1760-1815). A magyar nyelvű nevelési és életvezetési kézikönyvek kultúrtörténetéhez = A zsoltártól a rózsaszín regényig... 163-176.

KÉRI Katalin: „Nők csak mértékkel olvassanak...”. Adalékok a hazai női olvasóközönség 18-19. századi formálódásának történetéhez $=$ Pedagógia, oktatás, könyvtár... 319-341.

Korondi Ágnes: Író és olvasó nők a középkori Magyarországon $=$ A zsoltártól a rózsaszín regényig... 43-58. ill.

KUCSERKA Zsófia: Ismeretlen olvasónők = Studia litteraria 2014. 3/4. Emlékezet és irodalom. Kemény Zsigmond 1814-2014. 8794.

LÁszLó Zsófia, V.: Nőoktatás és könyves müveltség a 17-18. században $=$ A zsoltártól a rózsaszín regényig... 95-125. ill.

MésZÁros Márton: Néma olvasás, hangos olvasás a reformáció gyakorlatában $=$ Tempevölgy (6.) 2014. 3. 41-46.

Monok István: A németalföldi kiadványok aránya a 18. századi református értelmiség olvasmányaiban $=$ Történetek a mélyföldröl. Magyarország és Németalföld kapcsolata a kora újkorban / szerk. Bozzay Réka. Debrecen: Printart-Press, 2014. 280-295.

MonoK István: A női könyvtulajdonos, a női olvasó a 16-17. században = A zsoltártól a rózsaszín regényig... 79-93. ill.

OLÁH Róbert: Bibliák a kora újkori református lelkészi könyvtárakban = Egyháztört Szle (15.) 2014. 3. 8-23.

PAPP Júlia: Bevezetés $=$ A zsoltártól a rózsaszín regényig... 9-41. ill.

PAPP Júlia: „Ti vagytok a' polgári erény 's nemzetiség védangyali...”. Női olvasás a felvilágosodás és a kora reformkor időszakában $=$ A zsoltártól a rózsaszín regényig... 141-161. ill.

Pogány György: Fitz József olvasmányai és nézetei az olvasásról $=\mathrm{KN}$ (16.) 2014. 3. $61-74$.

PogÁny György: Női olvasás a reformkorban és az önkényuralom idején. Slachta Etelka, Kánya Emília olvasmányai, Jósika Júlia 
nézetei az olvasásról $=\mathrm{KN}$ (16.) 2014. 1 . 42-58.

SzEGEDY-MAsZÁk Zsuzsanna: Női olvasás a 19. századi Angliában $=$ A zsoltártól a rózsaszín regényig... 193-201.

VARGa Gabriella: A Herepei család könyves mủveltsége = Egyházi, családi és asszonykönyvtárak... 403-469.

\section{A múlt neves könyvtárosai, bibliográfusai, újságírói}

BERKE Barnabásné: Vajda Erik, 1930-2014 = KF (24.) 2014. 356-360.

BIRó Annamária: Identitáselemek egy 19. századi életpályában: Gottfried Feldinger/Földényi Frigyes = Certamen I.... 90-100.

BoKA László: Ö maga volt a bibliográfia. In memoriam Lakatos Éva, 1931-2014 = MKsz (130.) 2014. 4. 495-498.

Debreczeni-Droppán Béla: Sírok és temetések. A Magyar Nemzeti Múzeum főigazgatóinak végtisztessége. $1 .=$ Folia historica (29.) 2013. (2014.) 75-107. ill.

FöLDESI Ferenc: Könyvtár a magasban = Eltiporva. A vészkorszak és az Országos Széchényi Könyvtár. Az Országos Széchényi Könyvtár kiállítása. 2014. május 28-július 12. Tanulmányok a vészkorszakról és történelmi előzményeiről / szerk. UJvÁRY Gábor. Bp.: OSZK, 2014. 42-64. ill. Halász Gáborról (1901-1945)

GyaluI Farkas: Emlékirataim, 1914-1921. Sajtó alá rend., jegyz., előszó SAS Péter. Kolozsvár: Művelődés Egyes., 2013. 486 p. ill.
HAY Diana: Kovács Máté akadémiai könyvtári tevékenysége $=$ KF (24.) 2014. 4. 514-526.

KÉGLI Ferenc: „,Téged kedves barátom ezennel ünnepélyesen felkérlek...”. Id. Szinynyei József (1830-1913) első kurrens sajtó-bibliográfiája $=$ Szinnyei és követői... 31-54.

NAGY Anikó: Fügedi Péternétől (1928-2014) búcsúzunk $=\mathrm{KF}$ (24.) 2014. 3. 361-364.

NAGY Anikó: „Nekem a könyvtári szolgálat hivatás volt”. Busa Margit (1914-2009) sokszínü pályája és hagyatéka $=$ Szinnyei és követői... 124-147. ill.

PogÁny György: Fitz József (1888-1964) és a bibliográfia $=$ Szinnyei és követői... 82100.

Szemelvények idősb Szinnyei József kéziratos hagyatékából [elektr. dok.]. 1. levelezése alapján, 2. naplójegyzetei nyomán / közread. Gyurcsó Júlia. Baja: EJF K., 2014. Elektr. hely és hozzáférés: <http://nbn.urn. hu/N2L?urn:nbn:hu-130481>

Szinnyei és követői. Id. Szinnyei József halálának 100. évfordulójáról megemlékező centenáriumi emlékkönyv / szerk. SzŐNYI Éva. Bp.: OSZK-Gondolat-MKE, 2014. 185 p. ill. (Nemzeti téka)

SzöGI László: Id. Szinnyei József (1830-1913) az Egyetemi Könyvtár élén = Szinnyei és követöi... 55-60.

VAss Johanna: Dezsényi Béla (1907-1972) és sajtóbibliográfiai öröksége $=$ Szinnyei és követői... 101-123.

BoRvÖLGYI GYÖRGYI - HegYKÖZI ILONA (közremük. Kollár MÁRIA) 